\title{
MUNKÁVAL KAPCSOLATOS MOTIVÁCIÓK ÉS ELÉGEDETTSÉG - SZEMÉLYORIENTÁLT ELEMZÉS
}

\author{
FÉNYSZÁROSI ÉVA ${ }^{1}$ - SALLAY VIOLA ${ }^{1}$ - MATUSZKA BALÁZS² - \\ MARTOS TAMÁS ${ }^{1}$
}

\author{
${ }^{1}$ Szegedi Tudományegyetem, Pszichológiai Intézet \\ ${ }^{2}$ Pázmány Péter Katolikus Egyetem, Pszichológiai Intézet \\ E-mail: fenysz.eva@gmail.com
}

Beérkezett: 2018. február 24. - Elfogadva: 2018. szeptember 20.

\begin{abstract}
A legtöbb felnôtt ember életének jelentôs részét képezi a munkavégzés, így az, hogy mi motiválja óket ebben, nagy szerepet játszik a mindennapjaikban. Kutatásunkban 1662 magyar munkavállaló munkahelyi motivációs mintázatait vizsgáltuk az öndetermináció elméletének tükrében. A Többdimenziós Munkamotiváció Skála (Gagné és mtsai, 2015) alskáláinak klaszterelemzése során öt munkahelyi motivációs profil különült el, melyek a következók: (1) „belsôleg motiváltak”, (2) „kiegyensúlyozottak”, (3) „rendkíü̈l motiváltak”, (4) „alulmotiváltak”és (5) „külsóleg motiváltak”. A további elemzések arra utalnak, hogy a klaszterek által reprezentált munkavállalói csoportok jelentôsen különböznek a munkahelyen megélt három pszichológiai alapszükséglet, az autonómia-, kompetencia- és kapcsolódásélmény megtapasztalásának gyakoriságában. Ezen felül eltérốn itélik meg elégedettségüket az életükkel és a munkájukkal, eltérố mértékú stresszt tapasztalnak munkahelyükön, továbbá munkahelyváltási szándékuk is jelentôsen különbözik. A munkavégzésre irányuló motiváció tehát kihatással van az emberek jóllétére, és ezáltal mindennapi életükre is.
\end{abstract}

Kulcsszavak: munkamotiváció, öndetermináció elmélete, munkával való elégedettség, személyorientált megközelités, klaszterelemzés 
„Válassz olyan munkát, amit szeretsz, és egy napot sem kell dolgoznod az életedben." (Konfuciusz)

Ha elfogadjuk Konfuciusz gondolatának az igazságát, arra a következtetésre juthatunk, hogy aki dolgozik, az olyasvalamit csinál, amit nem szeret. Feltételezhetjük, hogy a munkavégzésre pusztán a mindennapi megélhetésre való törekvés, vagyis valamilyen külsố motiváló tényezô készteti. A szeretettel végzett munka ehhez képest vajon mitôl más - és más-e valóban? A munka és a munkahely, annak minden aspektusával a legtöbb felnôtt életének jelentôs részét képezi: a foglalkoztatási arány Európai Uniós átlagértéke a 20-64 éves lakosság körében 2016-ban 71,5\% volt (Központi Statisztikai Hivatal, 2017). Ha tehát a munkavégzés nem belsô indíttatásból történik, akkor az ember idejének java részét olyan tevékenység tölti ki, melyet nem szívesen végez. Ha az embert csupán a külsố jutalmak megszerzése (vagy büntetések elkerülése) és ilyen módon a szelffel kevéssé kongruens célok elérése vezérli, az negatív hatással van egyebek közt tevékenységének hatékonyságára, testi és lelki jóllétére, érzelmeire, önmegvalósítására és vitalitására (Deci és Ryan, 2000). Mind a lelki és testi egészség, mind pedig a munkavégzés valódi hatékonysága szempontjából alapvető, hogy az ember mennyire és miként motivált munkájának végzésére.

Jelen kutatás célja az öndeterminációs elmélet alapján kidolgozott munkamotivációs elmélet bemutatása és empirikus vizsgálata, melynek során a nemzetközi, valamint a hazai szakirodalomban is egyre inkább teret nyerô megközelítést, a személyorientált elemzési módot (Bergman és Lundh, 2015; Bergman, Magnusson és Khouri, 2003; Vargha, Torma és Bergman, 2015) alkalmazzuk.

\section{AZ ÖNDETERMINÁCIÓ ELMÉLETE AZ ÖNSZABÁLYOZÁSRÓL}

Az öndetermináció elmélete szerint a motiváció egy kontinuum mentén határozható meg, amelynek egyik végpontja a teljes mértékben kívülrôl kontrollált viselkedés, az extrinzik motiváció, másik végpontja az autonóm, önirányított viselkedés, az intrinzik motiváció. Ezen kívül helyezkedik el az amotiváció, ami mind az autonóm, mind a kontrollált viselkedéssel szemben áll, mert ilyenkor a személy nem mutat semmilyen szándékot, motivációt a cselekvés végrehajtására, tehát az adott viselkedéssel kapcsolatban az önirányítottság teljes hiányát mutatja (1. ábra, Deci és Ryan, 2000, 2008). Mivel a hazai szakirodalomban ezeknek az önszabályozási és motivációs módoknak a bemutatása már részletesen megtalálható (Martos, 2009, 2016), itt csak röviden utalunk az egyes szabályozási módokra (vö. Deci és Ryan, 2000). Intrinzik motivációról olyan esetekben beszélhetünk, amikor a személy a cselekvést kifejezetten a cselekvésért önmagáért végzi, azért mert azt érdekesnek és élvezetesnek találja. Amennyiben nem teljes mértékben ez a helyzet, akkor extrinzik szabályozásról beszélhetünk, ennek azonban számos fokozata van. A külsố szabályozás az extrinzik motiváció legnyilvánvalóbb esete. A személy külsố megerôsítések érdekében cselekszik, hogy elkerüljön valamilyen büntetést vagy külsố jutalmat kapjon. Introjektált szabályozás során a személy belsô kényszerek hatására cselekszik (például szorongás, búntudat elkerülése), melyek a külsó szabályozások bizonyos mértékig internalizált eredményei. Az identifikált szabályozás 
Viselkedés

Nem öndeterminált

A motiváció típusa

A szabályozás típusa

Az okozás észlelt helye

\section{Amotiváció \\ Extrinzik motiváció}

Öndeterminált

Intrinzik motiváció

Belső szabályozás

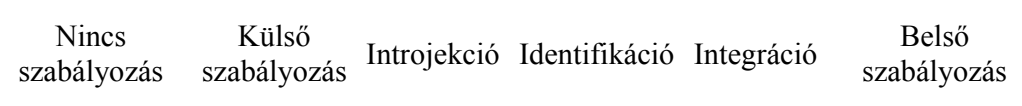

\begin{tabular}{cccccc}
\hline $\begin{array}{c}\text { Személytől } \\
\text { független }\end{array}$ & Külső & $\begin{array}{c}\text { Inkább } \\
\text { külső }\end{array}$ & $\begin{array}{c}\text { Inkább } \\
\text { belső }\end{array}$ & Belső & Belső
\end{tabular}

1. ábra. Az öndetermináció elméletének motivációs kontinuuma

Forrás: Deci és Ryan (2000)

alapja, hogy az egyén felismeri és elfogadja a viselkedés alapját képezó értékeket, és azonosul azokkal. Az extrinzik motiváció internalizációjának legteljesebb változata az integrált szabályozás, mely az elfogadott értékeket integrálja a szelf más vonatkozásaival. Egy átfogóbb felosztás szerint pedig az autonóm motiváció magába foglalja az intrinzik és az identifikált szabályozást. Ezzel ellentétben a kontrollált motiváció külsô és introjektált szabályozásból áll (Deci és Ryan, 2000, 2008).

A szabályozás észlelt helyének modelljével az öndetermináció elmélete a motiváció mennyisége helyett annak minôségére összpontosít (Deci és Ryan, 2000, 2008). Számos kutatás bizonyította, hogy az autonóm motivácó (belsô, integrált és identifikált szabályozás) és a kontrollált motiváció (introjektált és külsô szabályozás) egészen más következményekhez vezetnek (pl. Deci és Ryan, 2000; Teixeira, Carraça, Markland, Silva és Ryan, 2012). Az autonóm motiváció jellemzôen jobb testi és lelki egészséget, pozitívabb érzelmeket, magasabb fokú kompetenciát és elkötelezôdést, s a heurisztikus típusú tevékenységeken való hatékonyabb teljesítményt eredményez, mint a kontrollált motiváció (Deci és Ryan, 2000, 2008; Teixeira és mtsai, 2012). A belsô motiváció pozitív kapcsolatban áll továbbá a cél felé történô eredményes haladással (Koestner, Otis, Powers, Pelletier és Gagnon, 2008), és a viselkedés hosszabb távú fennmaradásához vezet (Deci és Ryan, 2000; Teixeira és mtsai, 2012). Az extrinzik célok - melyek külsô jutalom vagy mások dicséretének megszerzésére irányulnak - negatív összefüggésben állnak a jólléttel, és pozitívan korrelálnak a szorongással, míg az intrinzik célok - melyek kielégítik az ember alapvetô pszichológiai szükségleteit - a jólléttel mutatnak pozitív összefüggést, a szorongással negatívat (Kasser és Ryan, 1996).

\section{AZ ÖNDETERMINÁCIÓ ELMÉLETE ÉS A MUNKAMOTIVÁCIÓ}

A kontrollált munkahelyi motiváció kimeríti a proaktív viselkedésben jelen lévô erôforrásokat, és ha kompenzálásképp nem figyelhetô meg autonóm motivációból származó pozitív energiafelszabadulás, akkor erôforráshiány, és ennek megfelelôen 
munkahelyi stressz lép fel (Strauss, Parker és O’Shea, 2017). Ugyanis amikor a munkavállalók munkájuk során kontrollált motivációt tapasztalnak, miközben a proaktív viselkedésben nem figyelhetô meg autonóm motiváció, a proaktív célszabályozó folyamat kevésbé lesz hatékony, és ennek következtében nagy valószínúséggel csalódást és kudarcélményt tapasztalnak, ami növeli az erôforrás-kimerülést és a stresszválasz megjelenésének valószínúségét/az észlelt stressz mértékét (Strauss és mtsai, 2017). Minél internalizáltabb a motiváció, vagyis minél inkább önirányított az egyén, annál pozitívabb a munkahelyhez való hozzáállása (Graves, Cullen, Lester, Ruderman és Gentry, 2015).

A motivációkutatások egy csoportja az öndetermináció elméletét alapul véve személyorientált megközelítéssel vizsgálja a motiváció terén megjelenô egyéni különbségeket (például Friederichs, Bolman, Oenema és Lechner, 2015; Gillet, Fouquereau, Vallerand, Abraham és Colombat, 2017; Graves és mtsai, 2015; Howard, Gagné, Morin és Van den Broeck, 2016). E megközelítés által jobban megérthetjük az egyénen belüli különbözô motivációs szabályozások egyidejú létezését (Friederichs és mtsai, 2015; Moran, Diefendorff, Kim és Liu, 2012). Ennek oka, hogy a motiváció „változóközpontú” vizsgálata figyelmen kívül hagyja a lehetôséget, hogy természetesen elkülönülố motivációs együttállások is léteznek, és hogy az öndetermináció elméletén alapuló általános motivációs mintázatok, vagyis profilok különféle összhangban lehetnek más változókkal (Moran és mtsai, 2012). Egy motivációs profil a különbözó motivációk pontszámainak sajátos mintázatát tükrözi, mely több diagnosztikai információt hordoz, mint az egyes pontszámok az elkülönített motivációs dimenziókon (Vansteenkiste, Sierens, Soenens, Luyckx és Lens, 2009). A motivációs profilok így nemcsak magas vagy alacsony önirányítottságot tükrözhetnek, hanem egyszerre autonóm és kontrollált motivációs formák kialakulását is jelezhetik (Gillet és mtsai, 2017; Moran és mtsai, 2012; Van den Berghe és mtsai, 2014; Van den Broeck, Lens, De Witte és Van Coillie, 2013).

Graves, Cullen, Lester, Ruderman és Gentry (2015) menedzserek körében hat, Moran, Diefendorff, Kim és Liu (2012) munkakörök szempontjából kiterjedt kutatásukban öt különbözô munkahelyi motivációs profilt különböztettek meg. Két, tanárokat vizsgáló tanulmány (Jansen in de Wal, den Brok, Hooijer, Martens és van den Beemt, 2014; Van den Berghe és mtsai, 2014) és három, különbözô munkatevékenységet elemzô kutatás (Gillet és mtsai, 2017; Howard és mtsai, 2016; Van den Broeck és mtsai, 2013) azonban négy motivációs klasztert tárt fel a munkavállalók körében. A profilok különböztek a munkával való elégedettség és elkötelezettség (Gillet és mtsai, 2017; Graves és mtsai, 2015; Howard és mtsai, 2016; Van den Broeck és mtsai, 2013), az észlelt munkahelyi környezet, a pszichológiai alapszükségletek kielégítettsége, a munkahelyi teljesítmény (Moran és mtsai, 2012), a kiégés (Gillet és mtsai, 2017; Howard és mtsai, 2016; Van den Berghe és mtsai, 2014; Van den Broeck és mtsai, 2013), a szorongás, a munkahelyi élet minôsége, valamint az észlelt szervezeti támogatás (Gillet és mtsai, 2017) tekintetében.

Graves és munkatársai (2015) az önirányított, nagy mértékú belsô motivációval rendelkezô profilokat nagyfokú munkahelyi elégedettséggel és szervezeti elkötelezettséggel hozták összefüggésbe, miközben azt találták, hogy az alacsony belsô motivációjú 
csoportba tartozó menedzserek munkahelyváltási szándéka a legmagasabb. Ezzel összhangban Gillet és munkatársai (2017) kutatásukban rámutattak, hogy az autonóm módon motivált profilok magasabb munkahelyi elköteleződéssel és elégedettséggel rendelkeznek, illetve munkahelyi életük minôsége is jelentôsen jobb, mint az alacsony vagy közepes mértékú autonóm motivációval rendelkezô profiloké, miközben a kiégés és a munkahelyi szorongás esetükben a legalacsonyabb mértékú. Mindezek mellett az autonóm módon motivált profilok munkahelyi teljesítménye és jólléte is magasabb fokú, mint az efféle motivációval nem vagy csak kevéssé rendelkezó klasztereké (Howard és mtsai, 2016).

A korábban említett hét, munkahelyi motivációt vizsgáló tanulmány meglehetôsen különböző motivációs profilokra derített fényt, akadnak azonban kutatásokon átívelō, hasonló mintázatú klaszterek is. A hét kutatásból háromban is megjelenik egy olyan profil, melyet közepes mértékú extrinzik motiváció, jelentős mértékú introjektált, identifikált szabályozás és erôs intrinzik motiváció jellemez (Graves és mtsai, 2015; Howard és mtsai, 2016; Moran és mtsai, 2012). Több kutatásban is kirajzolódik továbbá közepes mértékú extrinzik és intrinzik motivációval, és szintén közepes mértékú introjektált és identifikált szabályozással rendelkezó profil (Gillet és mtsai, 2017; Howard és mtsai, 2016; Moran és mtsai, 2012; Van den Berghe és mtsai, 2014). Emellett két kutatás talált olyan klasztert, melyre alacsony mértékú extrinzik motiváció, közepes mértékú introjektált szabályozás és erôs identifikált szabályozás és intrinzik motiváció jellemzô (Graves és mtsai, 2015; Jansen in de Wal és mtsai, 2014). Friederichs és munkatársai (2015) kutatásukban a fizikai aktivitás motivációs mintázatait vizsgálták, és a három elkülönüló motivációs profilból egy szintén ez utóbbi mintázatot mutatta.

\section{Jelen kutatás bemutatása}

Az öndetermináció elméletén alapuló, munkahelyi motivációs mintázatokat vizsgáló kutatások többsége négy motivációtípusra épült, ezért kutatásunkban mi is az extrinzik motiváció, az introjektált és identifikált szabályozás, valamint az intrinzik motiváció mentén vizsgáltuk a motivációs mintázatokat (Graves és mtsai, 2015; Jansen in de Wal és mtsai, 2014; Van den Berghe és mtsai, 2014). Az amotivációt a korábban említett, munkamotivációt vizsgáló tanulmányok közül mindössze egy kutatás vonta be klaszterelemzésébe, ezért mi is mellôztük ezt jelen kutatás során (Howard és mtsai, 2016). Mivel korábbi tanulmányok eltérố számú munkahelyi motivációs klasztert tártak fel, kutatásunkban nem fogalmaztunk meg hipotézist a várható motivációs profilok pontos számára vonatkozóan. Minôségi szempontból feltételeztük azonban (1. hipotézis), hogy a klaszterelemzés során elkülönül majd egy „önirányított” profil közepes mértékú extrinzik motivációval, magas introjektált, identifikált szabályozással és magas intrinzik motivációval, egy „közepesen motivált” profil közepes mértékú extrinzik és intrinzik motivációval és szintén közepes mértékú introjektált és identifikált szabályozással, valamint egy „autonóm” profil, melyet alacsony extrinzik motiváció, közepes mértékú introjektált szabályozás és magas identifikált szabályozás és intrinzik motiváció jellemez. 
Az autonóm szabályozású viselkedés korábban említett pozitív következményei a három pszichológiai alapszükséglet magasabb fokú kielégülésével magyarázhatók, ugyanis nincs megfelelố internalizáció és intrinzik motiváció az autonómia, kompetencia és kapcsolódás szükségletének kielégülése nékül (Deci és Ryan, 2000). A klaszterelemzés során feltárt profilokat összehasonlítottuk a munkahelyen tapasztalt autonómia-, kompetencia- és kapcsolódásélmény mértékével. Feltételeztük (2. hipotézis), hogy az autonóm módon motivált profil(ok) esetén jelentôsebb lesz a három alapszükséglet (autonómia, kompetencia és kapcsolódás) kielégülésének mértéke, mint az ezen szabályozással nem vagy csak kismértékben rendelkezô profilok esetén. A klasztereket ezen felül megvizsgáltuk az élettel és a munkával való elégedettség (mint lehetséges pozitív tapasztalatok) tekintetében, illetve a munkahelyváltási szándék és a munkában észlelt stressz (mint a munkával kapcsolatos lehetséges negatív következmények) vonatkozásában is.

\section{MÓDSZER}

\section{Vizsgálati minta}

Az adatfelvétel kényelmi mintavételezéssel történt 2014 és 2017 között, az elemzéseket 1662 fôs adatbázison végeztük. Jelen kutatás a Szegedi Tudományegyetem Pszichológiai Intézetében és a Pázmány Péter Katolikus Egyetem Pszichológiai Intézetében folyó közös tudományos kutatás keretein belül valósult meg, melynek központi témája a munkahelyi jóllét, és ennek személyes és társas meghatározói voltak. A mintavétel során a foglalkozást, illetve a munka típusát tekintve heterogenitásra törekedtünk, így e tekintetben nem szabtunk semmilyen kikötést. A kutatásban való részvétel kritériuma a 18. életév betöltése volt, mint a felnôtt, önálló döntéshozatal elméleti alsó határa; továbbá az, hogy a válaszadónak legyen legalább napi 4 órás munkája, annak érdekében, hogy a munkával kapcsolatos tapasztalatai rendszeres munkavégzésból származzanak.

A vizsgálati minta jellemzőit az 1. táblázatban közöljük. A vizsgálatban részt vevô 1662 fó 45,8\%-a férfi, 54,2\% nô volt. Életkor tekintetében a teljes minta 7,6\%-ára vonatkozóan nincs adatunk, a fennmaradó 92,4\% átlagéletkora 36,58 év volt (szórás: 11,66, medián: 35, módusz: 25). A minta 61,2\%-a egyetemi, főiskolai vagy magasabb iskolai végzettséggel, 12,2\%-a felsôfokú szakképzéssel, 22\%-a érettségivel, 4,1\%-a szakiskolai vagy szakmunkásképzó ipari iskolai végzettséggel, $0,5 \%$-a pedig 8 általános iskolai vagy ennél alacsonyabb végzettséggel rendelkezett. A minta 75,7\%-a szellemi munkát, 13,7\%-a pedig fizikai munkát végzô személy volt (10,6\% „egyéb”). A vizsgálati személyek 85,1\%-a teljes munkaidôben dolgozó, 11,9\%-a pedig részmunkaidôben foglalkoztatott személy volt (2,9\% „egyéb”), legtöbbjük, 70,8\%-uk önálló felelôsséggel rendelkezô alkalmazottként, 13,6\%-uk középvezetôként, 9,1\%-uk vállalkozóként, 4,9\%-uk felsôvezetôként dolgozó (1,7\% „egyéb”). A résztvevók 25,3\%-a 10 vagy több éve dolgozott az adott munkahelyén a kitöltés időpontjában, 14,8\%-uk 5-10 éve, 37,1\%-uk 1-5 éve, 16,4\%-uk 3-12 hónapja, 6,5\%-uk pedig 3 hónapnál kevesebb ideje. A válaszadók 53,9\%-ának munkahelye városban helyezkedett el, 35,9\%-uk a fôvárosban, Budapesten dolgozott, $5 \%$-uk pedig községben/faluban ( $5,2 \%$ „egyéb”). 
1. táblázat. A vizsgálati minta jellemzői

\begin{tabular}{|c|c|c|}
\hline & & $\begin{array}{c}\text { Elemszám } \\
\text { (a teljes minta \%-a) }\end{array}$ \\
\hline \multirow[t]{2}{*}{ Nem } & férfi & $761(45,8)$ \\
\hline & nô & $901(54,2)$ \\
\hline Átlagéletkor (szórás) & 36,58 év $(11,66)$ & $1536(92,4)$ \\
\hline \multirow[t]{5}{*}{ Iskolai végzettség } & $\begin{array}{l}\text { egyetemi, föiskolai oklevél vagy } \\
\text { magasabb }\end{array}$ & $1017(61,2)$ \\
\hline & felsőfokú szakképzés & $202(12,2)$ \\
\hline & érettségi & $366(22)$ \\
\hline & $\begin{array}{l}\text { szakiskola, ipari iskola, } \\
\text { szakmunkásképzô }\end{array}$ & $68(4,1)$ \\
\hline & 8 általános vagy kevesebb & $9(0,5)$ \\
\hline \multirow[t]{3}{*}{ Foglalkozási kategória } & szellemi munka & $1258(75,7)$ \\
\hline & fizikai munka & $227(13,7)$ \\
\hline & egyéb & $177(10,6)$ \\
\hline \multirow[t]{3}{*}{ Munkaidố } & teljes munkaidô & $1415(85,1)$ \\
\hline & részmunkaidô & $198(11,9)$ \\
\hline & egyéb & $49(2,9)$ \\
\hline \multirow[t]{5}{*}{ Munkahelyi beosztás } & alkalmazott (önálló felelôsséggel) & $1176(70,8)$ \\
\hline & középvezetó & $226(13,6)$ \\
\hline & vállalkozó & $151(9,1)$ \\
\hline & felsôvezetô & $82(4,9)$ \\
\hline & egyéb & $27(1,7)$ \\
\hline \multirow[t]{5}{*}{$\begin{array}{l}\text { Munkaévek az adott } \\
\text { munkahelyen }\end{array}$} & 10 vagy több év & $420(25,3)$ \\
\hline & 5-10 év & $246(14,8)$ \\
\hline & $1-5$ év & $616(37,1)$ \\
\hline & 3-12 hónap & $272(16,4)$ \\
\hline & kevesebb, mint 3 hónap & $108(6,5)$ \\
\hline \multirow[t]{4}{*}{$\begin{array}{l}\text { Munkahely } \\
\text { településtípusa }\end{array}$} & város & $896(53,9)$ \\
\hline & fôváros & $597(35,9)$ \\
\hline & község/falu & $83(5)$ \\
\hline & egyéb & $86(5,2)$ \\
\hline
\end{tabular}

\section{Eljárás és eszközök}

A kutatási kérdőívet online, a Surveygizmo weboldalon keresztül vettük fel. A kérdôívek kitöltése átlagosan 25-30 percet vett igénybe. A kitöltés megkezdése elôtt a kutatásban részt venni szándékozók tájékoztatást kaptak, miszerint a vizsgálatban való részvételük teljesen önkéntes és anonim, a kutatás során nyert adatok személyes azonosításra, illetve munkahelyük meghatározására nem adnak módot. A kutatáshoz elôzetesen megkaptuk az EPKEB etikai engedélyét is. 
Jelen kutatásban a teljes, 17 kérdôívbốl álló kérdốívcsomagból 5 kérdốív került felhasználásra. Emellett felmérésre került a résztvevốk munkahelyváltási szándéka („Milyen gyakran gondol arra, hogy új munkahelyet keres magának?”), melyet a válaszadók 10-fokú Likert-típusú skálán jelöltek ( 1 = soha, 10 = nagyon gyakran).

\section{Több Dimenziós Munkamotivációk Kérdôiv}

A munkahelyi motivációk felmérésére a Munkamotivációk Kérdôívet használtuk, melyben a válaszadók 7-fokú Likert-típusú skálán jelölhették, hogy az adott állítások milyen pontosan írják le az okokat, melyek miatt ốk energiát fektetnek a munkájukba (Gagné és mtsai, 2015; Matuszka és mtsai, 2018). A kérdốív 19 tétele ezzel felmérte a kitöltốk extriznik (tovább bontható társas és anyagi értelemben vett extrinzik motivációra), introjektált, identifikált és intrinzik motivációinak erôsségét (Cronbach-alfák: 0,784, 0,741, 0,852 és 0,912, a fenti sorrendben). A skálák kialakítása során összevonásra kerültek a társas és anyagi értelemben vett extrinzik motiváció pontszámai egy átlagolt extrinzik motivációs pontszámmá. A két pontszám átlagának kiszámítása elốtt elvégeztünk egy Pearson-féle korrelációs vizsgálatot, mely igazolta, hogy a társas és az anyagi értelemben vett extrinzik motiváció jelentôs mértékú pozitív együttjárást mutat $(r(1662)=0,479, p<0,001)$. A továbbiakban ezt az „összesített” extrinzik motivációt használtuk a klaszterelemzés során.

\section{Pszichológiai Alapszükégletek a Munkában Kérdốiv}

A Pszichológiai Alapszükégletek a Munkában Kérdôiv 9 tétele a vizsgálatban részt vevôk munkában megélt autonómia-, kompetencia- és kapcsolódásélményét felmérô méróeszköz (Cronbach-alfák: 0,764, 0,689 és 0,756, a fenti sorrendben), melyben a vizsgálati személyek 7-fokú Likert-típusú skálán jelölhették, mennyire értenek egyet a kérdôív egy-egy állításával (Deci és mtsai, 2001). Ezzel a válaszadók munkahelyi pszichológiai alapszükségleteinek személyes tapasztalatairól tudhattunk meg többet. A kérdő́v jelen kutatásban használt 9 tételes változata egy rövidített verzió, melynek magyarországi validálása jelenleg zajlik.

\section{Élettel Való Elégedettség Kérdốv}

A szubjektív jóllét és boldogság - azaz az élettel való elégedettség - meghatározása az Élettel Való Elégedettség Kérdôívvel történt, mely az élettel való szubjektív elégedettség kognitív, értékelô összetevőjét mérô öttételes mérôeszköz (Martos, Sallay, Désfalvi, Szabó és Ittzés, 2014). A válaszadók 7-fokú Likert-típusú skálán jelölhették, hogy menynyire értenek egyet a kérdốív adott állításaival (Cronbach-alfa: 0,883).

\section{Munkával Való Elégedettség Kérdồiv}

A munkával kapcsolatos elégedettség felmérése az öttételes Élettel Való Elégedettség Kérdôív tételeinek átfogalmazásával készült, a jelen kutatás számára (pl. „A munkám a legtöbb tekintetben közel van az ideálishoz”). A válaszadók 7-fokú Likert-típusú ská- 
lán jelölhették, hogy mennyire értenek egyet a kérdôív adott állításaival. Bár a kérdôívet külön nem validáltuk, belsố megbízhatósága kiválónak bizonyult (Cronbach-alfa: 0,855), és az eredeti kérdốivvel való lényegi hasonlósága is a validitása mellett szól.

\section{Rövid Észlelt Stressz Skála a Munkában}

A Rövid Észlelt Stressz Skála a Munkában a munkával kapcsolatban észlelt stressz mennyiségét becslô skála, melyet a négytételes Rövid Észlelt Stressz Skála (Stauder és Konkoly Thege, 2006) instrukciójának kismértékú átfogalmazásával alkalmaztumk, és a munkában tapasztalt stressz mennyiségét lehet becsülni vele. A válaszadók 5-fokú Likert-jellegû skálán jelölhették, hogy a 4 állítás mennyire volt rájuk jellemzô az elmúlt idôszakban (pl. „Úgy érezte, hogy képtelen kézben tartani azokat a dolgokat, amelyek fontosak a munkájában”). A kérdôív belsố megbízhatósága megfelelố volt (Cronbach-alfa: 0,694).

\section{Az elemzési folyamat áttekintése}

Az adatok elemzésére és feldolgozására az IBM SPSS Statistics 22.0 programot használtuk. A motivációs profilok kialakítása a ROPstat statisztikai szoftverrel történt, és mint már korábban említésre került, a profilok elkülönítése négy változó - az extrinzik motiváció, az introjektált és identifikált szabályozás, valamint az intrinzik motiváció mentén történt. Az elemzésbe bevont változók alapvetô leíró jellemzőit a 2. táblázatban adjuk meg.

Az elôzetes adatelemzés és leíró statisztikák futtatása után a klaszterelemzés alapjául szolgáló MWMS-H alksálák alapján lehetséges kilógó (outlier) eseteket kerestünk a mintában. Ennek értelme az, hogy néhány kilógó eset a saját jelentôségéhez képest jóval nagyobb mértékben képes befolyásolni a klaszterelemzés eredményét (pl. Bergman, Magnusson és El-Khouri, 2003, 109-110). A kilógó esetek kizárása után az MWMS-H alksáláin klaszterelemzést végeztünk a ROPstat statisztikai programcsomag mintázatfeltáró modulja segítségével (Vargha, 2016; Vargha és mtsai, 2015). Egy iterációs folyamat során meghatároztuk a leginkább megfelelố klaszterszámot (vö. Takács, Makrai és Vargha, 2015; Vargha, Bergman és Takács, 2016). Az így kialakított klasztertagságokat egyrészt értelmeztük, továbbá egy sor ANOVA-elemzés során összevetettük a válaszadók további jellemzôivel.

\section{EREDMÉNYEK}

\section{Klaszterelemzés}

Elsôként Vargha és munkatársai (2015) ajánlásainak megfelelôen hierarchikus klaszterelemzést futtatunk az MWMS-H négy alskálájának pontszámain (externális, introjektált, integrált és intrinzik munkamotiváció) és a 3-tól 10 klaszteres megoldások 


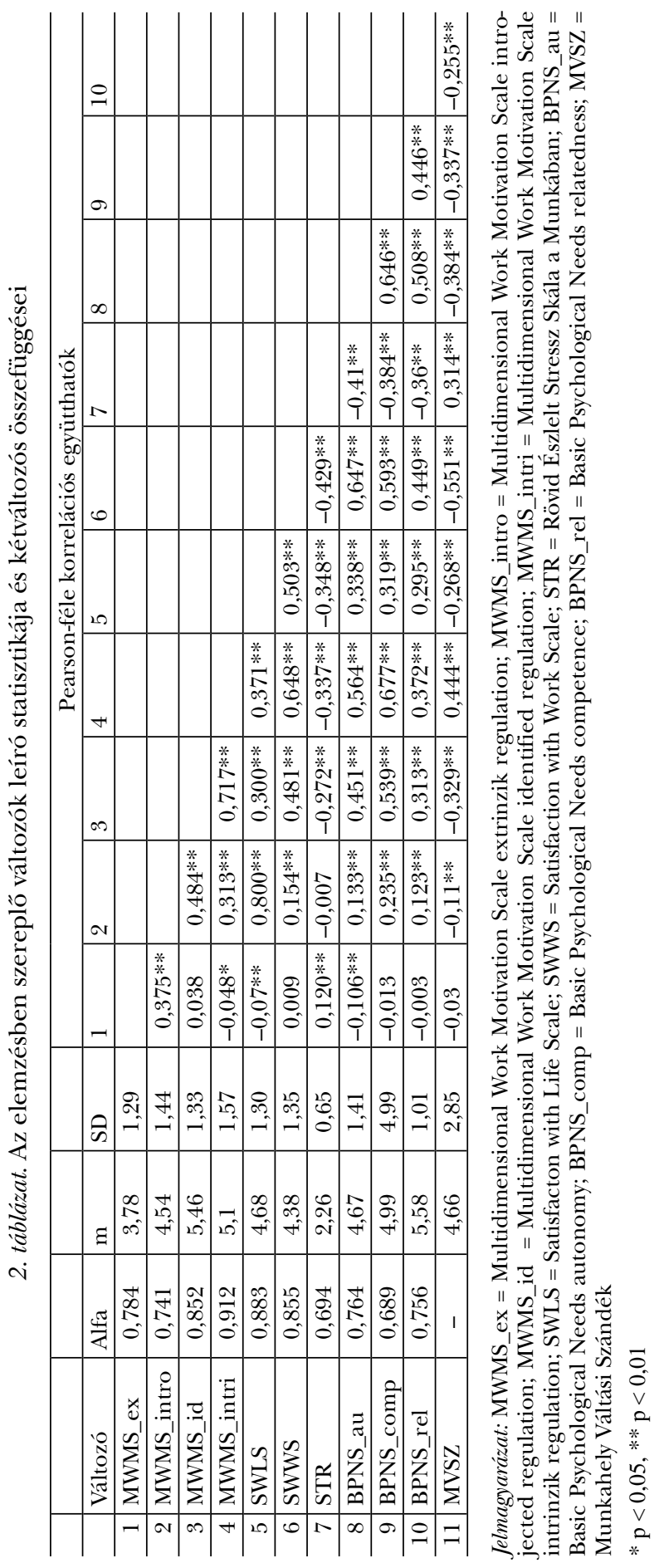


megfelelôségi mutatóit vetettük össze. A klaszterelemzést standardizált változókon végeztük, Ward eljárással, négyzetes Euklideszi távolságok módszerével, mivel ez az eljárás maximalizálja a csoportok közötti, és minimalizálja a csoporton belüli különbségeket. Az elsố klasztermegoldásokat a megfelelóségi mutatók szerint hasonlítottuk össze: megmagyarázott hibaszázalék (Explained Error Sum of Squares - EESS \%; lehetôleg nagyobb, mint 60\%), pontbiszeriális korreláció (lehetôleg nagyobb, mint 0,3), Silhouette-együttható (lehetôleg nagyobb mint 0,5), módosított Xie-Beni-index (minél nagyobb legyen, illetve lokális maximum szükséges) és átlagos klaszterhomogenitás (HC-átlag, lehetôleg kisebb mint 1,0). A feltüntetett elvárt határértékeket Vargha és munkatársai (2016) alapján adtuk meg.

A mi elemzésünkben talált klasztermegoldások jellemzôit a 3. táblázatban közöljük. A végleges klaszterszámot egyrészt a megfelelôségi mutatók, másrészt a klaszterek értelmezhetôségének szempontjai szerint alakítottuk ki. Az adatok alapján úgy találtuk, hogy az ötklaszteres megoldás megfelelố részletességgel és pontossággal reprezentálja az adatokat, miközben lehetôvé teszi az egyes klaszterek egymástól való megkülönböztetését, és így az értelmezést is. Valamennyi adekvációs index az elvárt tartományban vagy annak közelében volt, a Xie-Beni-index pedig lokális maximumot mutatott. A klaszterek számának meghatározása után újrafuttattuk az elemzést, ezúttal viszont relokációt is kértünk az ötklaszteres megoldásra. A relokáció tovább növelte a modell által magyarázott varianciát (56,08\%-ról 61,4\%-ra), s így már a Silhouette-együttható is 0,5 feletti értéket vett fel. A végleges klasztertagságot a további elemzések számára elmentettük. Az öt klaszter részletes adatai az 2. táblázatban láthatóak. Az egyes klaszterek számaránya a mintán belül 7,6\% és 27,3\% között alakult, ami a két alcsoport között valamivel kisebb mint 4-szeres különbség, ami még megfelelốen kiegyensúlyozott csoportosításnak tekinthetô.

A következôkben azt vizsgáltuk meg, hogy az elkülönülő profilok jelentôsen különböznek-e a négy motivációtípus tekintetében. Az egyes motivációs skálákon elért átlagok statisztikai különbségének tesztelésére egyszempontos varianciaanalízist alkalmaztunk, melyben a csoportosító változó az ötklaszteres megoldás, a függố változó

3. táblázat. A hierarchikus klaszterelemzés adekvációs indexei, 3-10 klaszteres megoldások

\begin{tabular}{l|c|c|c|c|c|c}
\hline Lépés & $\mathrm{N}$ & EESS \% & $\begin{array}{c}\text { Pont- } \\
\text { biszeriális eh. }\end{array}$ & $\begin{array}{c}\text { XieBeni } \\
(\mathrm{mod})\end{array}$ & $\begin{array}{c}\text { Silhouette } \\
\text { eh. }\end{array}$ & HC átlag \\
\hline $\mathrm{i}=1652$ & 10 & 68,14 & 0,282 & 0,066 & 0,377 & 0,641 \\
\hline $\mathrm{i}=1653$ & 9 & 66,38 & 0,306 & 0,584 & 0,399 & 0,676 \\
\hline $\mathrm{i}=1654$ & 8 & 64,54 & 0,307 & 0,157 & 0,395 & 0,713 \\
\hline $\mathrm{i}=1655$ & 7 & 62,55 & 0,314 & 0,324 & 0,41 & 0,752 \\
\hline $\mathrm{i}=1656$ & 6 & 59,35 & 0,323 & 0,128 & 0,412 & 0,816 \\
\hline $\mathrm{i}=1657$ & 5 & 56,08 & 0,355 & 0,591 & 0,444 & 0,881 \\
\hline $\mathrm{i}=1658$ & 4 & 51,34 & 0,337 & 0,282 & 0,473 & 0,975 \\
\hline $\mathrm{i}=1659$ & 3 & 43,53 & 0,366 & 0,287 & 0,504 & 1,131 \\
\hline Relokáció után & 5 & 61,4 & 0,375 & 0,669 & 0,567 & 0,774 \\
\hline
\end{tabular}

Jelmagyarázat: N = a klaszterek száma; EESS \% = megmagyarázott hibaszázalék (Explained Error Sum of Squares); Pont-biszeriális eh. = pont-biszeriális korreláció; XieBeni $(\bmod )=$ módosított Xie-Beni index; HC átlag = átlagos klaszterhomogenitás 
pedig a négyféle - extrinzik, introjektált, identifikált és intrinzik - motivációtípus volt. A vizsgálatban kiderült, hogy a klaszterek átlagpontszámai szignifikáns mértékben különböznek az extrinzik motiváció $(F(4)=402,28, p<0,001)$, az introjektált $(F(4)=$ 434,62, $p<0,001)$ és identifikált $(F(4)=1043,98, p<0,001)$ szabályozás, valamint az intrinzik motiváció $(F(4)=954,62, p<0,001)$ tekintetében is. Hogy megtudjuk, pontosan mely csoportok között van jelentôs eltérés, Bonferroni utótesztet alkalmaztunk. A teszt eredményeit a 4. táblázat „Átlagpontszám” oszlopában felsô indexekkel jelöltük. A statisztikailag jelentôs mértékben eltérô átlagokat az egyes motivációtípusokon belül különbözó írásjelek jelölik. Tehát csak azon esetekben nem volt kimutatható szignifikáns eltérés az átlagok között, melyet egy motivációtípuson belül azonos betú jelöl a felsố indexben.

A pontosabb értelmezés érdekében a klaszterek vizuális megjelenítésekor (2. ábra) z-pontszámokkal operáltunk. Az elsố klaszter egy „belsôleg motivált” profil, melyet közepes mértékú extrinzik motiváció és introjektált szabályozás, valamint magas identifikált szabályozás és intrinzik motiváció jellemez. A második klaszter egy „közepesen

4. táblázat. Az öt elkülönülô motivációs klaszter elemszámai, továbbá az extrinzik motiváció, introjektált és identifikált szabályozás, valamint az intrinzik motiváció skáláján elért átlagpontszámai és az ehhez tartozó szórások. Az egyes motivációtípusokon belül eltérố felsố indexszel jelölt átlagok statisztikailag jelentős mértékben különböznek egymástól

\begin{tabular}{|c|c|c|c|c|}
\hline & Klaszter & Elemszám & Átlagpontszám & Szórás \\
\hline \multirow{6}{*}{ Extrinzik motiváció } & 1 & 442 & $2,607^{\mathrm{a}}$ & 0,857 \\
\hline & 2 & 289 & $3,275^{\mathrm{b}}$ & 0,903 \\
\hline & 3 & 454 & $4,677^{\mathrm{c}}$ & 0,935 \\
\hline & 4 & 126 & $3,328^{\mathrm{b}}$ & 1,219 \\
\hline & 5 & 351 & $4,673^{\mathrm{c}}$ & 0,850 \\
\hline & Osszesen & 1662 & 3,780 & 1,286 \\
\hline \multirow{6}{*}{ Introjektált szabályozás } & 1 & 442 & $4,072^{\mathrm{a}}$ & 1,256 \\
\hline & 2 & 289 & $3,577^{\mathrm{b}}$ & 0,891 \\
\hline & 3 & 454 & $5,786^{c}$ & 0,895 \\
\hline & 4 & 126 & $2,393^{\mathrm{d}}$ & 1,039 \\
\hline & 5 & 351 & $5,084^{\mathrm{e}}$ & 0,844 \\
\hline & Összesen & 1662 & 4,541 & 1,436 \\
\hline \multirow{6}{*}{ Identifikált szabályozás } & 1 & 442 & $6,291^{\mathrm{a}}$ & 0,647 \\
\hline & 2 & 289 & $4,347^{\mathrm{b}}$ & 0,865 \\
\hline & 3 & 454 & $6,410^{\mathrm{a}}$ & 0,530 \\
\hline & 4 & 126 & $2,635^{c}$ & 0,913 \\
\hline & 5 & 351 & $5,131^{\mathrm{d}}$ & 0,771 \\
\hline & Összesen & 1662 & 5,463 & 1,334 \\
\hline \multirow{6}{*}{ Intrinzik motiváció } & 1 & 442 & $6,212^{\mathrm{a}}$ & 0,732 \\
\hline & 2 & 289 & $4,141^{\mathrm{b}}$ & 1,007 \\
\hline & 3 & 454 & $6,213^{\mathrm{a}}$ & 0,643 \\
\hline & 4 & 126 & $2,050^{c}$ & 0,830 \\
\hline & 5 & 351 & $4,161^{\mathrm{b}}$ & 1,118 \\
\hline & Összesen & 1662 & 5,103 & 1,570 \\
\hline
\end{tabular}




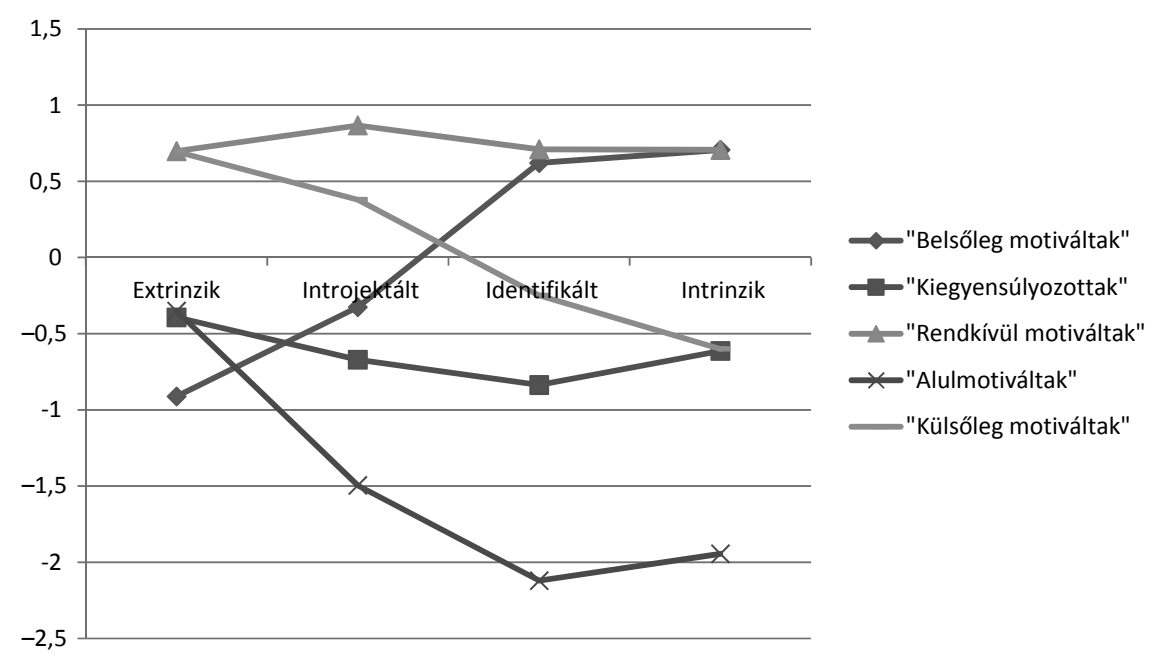

2. ábra. Az egyes profilok motivációs alskálákon elért pontszámai z-pontszámokban kifejezve

motivált" profilt takar, mely minden motivációtípus tekintetében közepes motiváltsággal jellemezhetô. A harmadikként elkülönülô klaszter „rendkívül motivált”, a profilra tehát mindegyik motivációtípus tekintetében magas motiváltság jellemzó, kiváltképp az introjektált szabályozást illetôen. A negyedik klaszter egy „alulmotivált” profil, mely három motivációtípust illetôen alacsony mértékú motivációt mutat, tehát jelentôsen alacsony introjektált és identifikált szabályozással, valamint intrinzik motivációval, ám ezeknél némileg magasabb, közepes mértékú extrinzik motivációval jellemezhetô. Az ötödik klaszter egy „külsôleg motivált” profilt takar, melyet magas extrinzik motiváció, közepesen magas introjektált szabályozás, valamint közepes mértékú identifikált szabályozás és intrinzik motiváció jellemez (2. ábra).

Kutatásunkban a három feltételezett profil közül kettô jelent meg: a „közepesen motivált” (itt: „kiegyensúlyozott”) és az „autonóm” (itt: „belsôleg motivált”) profil. Második hipotézisünket, miszerint az autonóm módon motivált profil(ok) esetén statisztikailag jelentôs mértékben magasabb lesz a három alapszükséglet - az autonómia, kompetencia és kapcsolódás - kielégítettsége, mint az ezen szabályozással nem vagy csak kis mértékben rendelkezô profilok esetén, egyszempontos varianciaanalízissel teszteltük. Ennek elsố lépéseként - az identifikált szabályozás és az intiznik motivációs pontszámokat átlagolva - kiszámításra került egy belsô, vagyis autonóm motivációs pontszám. Ehhez elôször Pearson-féle korrelációval megvizsgáltuk az identifikált szabályozás és intrinzik motiváció, vagyis az autonóm szabályozást alkotó motivációtípusok együttjárását. A próba során kiderült, hogy a két motivációtípus statisztikailag jelentôs mértékú pozitív együttjárást mutat $(r(1662)=0,72, p<0,001)$, tehát értékeik összevonhatók.

Ezt követốn végeztük el az egyszempontos varianciaanalízist, mely kimutatta, hogy a klaszterek átlagai autonóm szabályozás tekintetében szignifikánsan eltérnek $(F(4)$ 


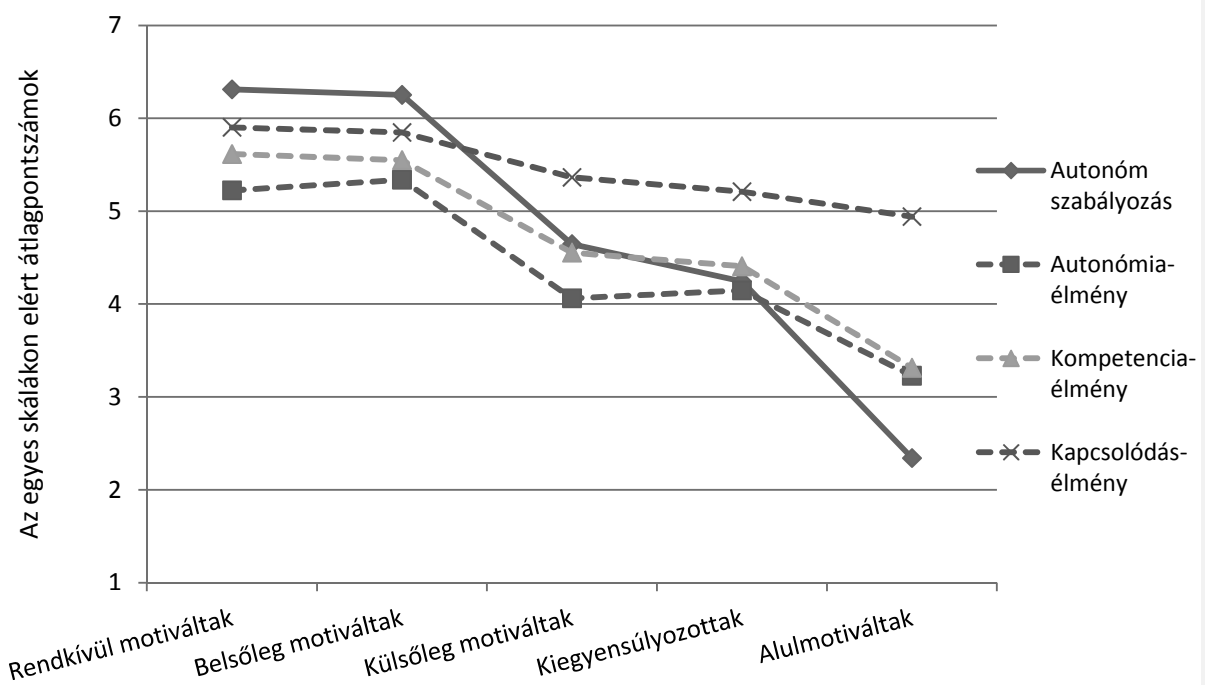

3. ábra. Az egyes profilok autonóm szabályozásának, autonómia-, kompetencia- és kapcsolódásélményének átlagpontszámai. Mindegyik skála tartománya 1-7-ig terjed, ahol az 1-es érték azt jelöli, hogy az adott állítás egyáltalán nem igaz a válaszadóra, a 7-es érték pedig azt, hogy teljes mértékben igaz rá

$=1764,96, p<0,001)$. Utótesztként Bonferroni-próbát alkalmaztunk, melynek során kiderült, mely klaszterek között van jelentôs különbség az autonóm szabályozást illetôen. A „rendkívül motiváltak” (átlag: 6,31, szórás: 0,47) és a „belsôleg motiváltak” (átlag: 6,25, szórás: 0,55) szignifikáns mértékben a leginkább autonómak, ôket követik a „külsôleg motiváltak” (átlag: 4,65, szórás: 0,7), majd a „kiegyensúlyozottak” (átlag: 4,24, szórás: 0,61), legkevésbé autonóm szabályozásúak pedig az „alulmotiváltak” (átlag: 2,34, szórás: 0,68; az eredményeket lásd a 3. ábrán is).

A munkahelyen megélt autonómia-, kompetencia- és kapcsolódásélmény klaszterek szerinti összehasonlítására is egyszempontos varianciaanalízist, majd Bonferroni-utótesztet alkalmaztunk. A varianciaanalízis kimutatta, hogy a klaszterek átlagai statisztikailag jelentôs mértékben eltérnek az autonómiaélmény $(F(4)=134,09, p<0,001)$, a kompetenciaélmény $(F(4)=211,17, p<0,001)$ és a kapcsolódásélmény $(F(4)=50,56$, $p<0,001)$ tekintetében is.

A munkahelyükön a legtöbb autonómiaélményt a „belsôleg motiváltak” (átlag: 5,34, szórás: 1,17) és a „rendkívül motiváltak” élik meg (átlag: 5,22, szórás: 1,1), óket követik azonos mértékben megélt munkahelyi autonómiával a „kiegyensúlyozottak” (átlag: 4,15, szórás: 1,3) és a „külsôleg motiváltak” (átlag: 4,06, szórás: 1,28), legkevésbé pedig az „alulmotiváltak” (átlag: 3,22, szórás: 1,48) tapasztalnak autonómiát a munkahelyükön. A munkahelyen megélt autonómiaélmény mértékének klasztersorrendje tehát megegyezik az autonóm szabályozás mértékének klasztersorrendjével, azzal az eltéréssel, hogy az autonómiaélmény tekintetében a „külsôleg motiváltak” és a „kiegyensúlyozottak" átlagértékei nem különböznek szignifikáns mértékben.. 
Munkahelyi kompetenciaélményt leginkább a „rendkívül motiváltak” (átlag: 5,62, szórás: 0,88) és a „belsôleg motiváltak” (átlag: 5,55, szórás: 0,94) tapasztalnak, tôlük azonos mértékben kevésbé élik ezt meg a „külsôleg motiváltak” (átlag: 4,55, szórás: 1,09) és a „kiegyensúlyozottak” (átlag: 4,41, szórás: 1,07), legkevésbé pedig az „alulmotiváltak" (átlag: 3,31, szórás: 1,12). A munkahelyen megélt kompetenciaélmény mértékének klasztersorrendje tehát megegyezik az autonóm szabályozás mértékének klasztersorrendjével, azzal a különbséggel, hogy a kompetenciaélmény tekintetében a „külsôleg motiváltak” és a „kiegyensúlyozottak” átlagértékei nem különböznek statisztikailag jelentős mértékben.

A legtöbb munkahelyi kapcsolat élményt a „rendkívül motiváltak” (átlag: 5,9, szórás: 0,85 ) és a „belsóleg motiváltak” (átlag: 5,85, szórás: 0,89) élik meg, óket követik azonos mértékben megélt kapcsolatélménnyel a „külsôleg motiváltak” (átlag: 5,36, szórás: 1) és a „kiegyensúlyozottak” (átlag: 5,2, szórás: 1,06), legkevesebb kapcsolatélményük pedig az „alulmotiváltaknak” (átlag: 4,94, szórás: 1,15) van a munkahelyükön, akiknek átlaga nem különbözik statisztikailag jelentős mértékben a „kiegyensúlyozottakétól”. A munkahelyen megélt kapcsolatélmény mértékének klasztersorrendje tehát megegyezik az autonóm szabályozás mértékének klasztersorrendjével, azzal az eltéréssel, hogy a kapcsolatélmény megélésének tekintetében a „külsôleg motiváltak” és a „kiegyensúlyozottak”, illetve a „kiegyensúlyozottak” és az „alulmotiváltak” átlagpontszámai nem különböznek szignifikáns mértékben. Ezt erôsíti továbbá a Pearson-féle korrelációs vizsgálat, mely szerint az autonóm szabályozás statisztikailag jelentôs pozitív együttjárást mutat a munkahelyen megélt autonómia- $(r(1662)=0,553, p<0,001)$, kompetencia- $(r(1662)=0,662, p<0,001)$ és kapcsolódásélménnyel $(r(1662)=0,372$, $p<0,001)$. Mindezek alapján elmondható, hogy hipotézisünk, mely szerint az autonóm módon motivált profil(ok) esetén statisztikailag jelentôs mértékben magasabb lesz a három alapszükséglet - az autonómia, kompetencia és kapcsolódás - kielégítettsége, mint az ezen szabályozással nem vagy csak kis mértékben rendelkezô profilok esetén, beigazolódott (3. ábra).

A klasztereket megvizsgáltuk továbbá az élettel és a munkával való elégedettség szempontjából, illetve a munkahelyváltási szándék és a munkában észlelt stressz tekintetében: ezek az eredmények a 4., 5. és 6. ábrán láthatók. A belsôleg és rendkívül motivált klaszterek átlagpontszámai mind a négy esetben megegyeztek: ez a két klaszter a legelégedettebb mind az életével, mind a munkájával, továbbá nekik legkisebb a munkaváltási szándékuk, s munkahelyükön ôk észlelik a legkevesebb stresszt. A külsôleg motivált és kiegyensúlyozott klaszterek élettel és munkával való elégedettsége a korábbi két profil értékeihez képest szignifikánsan kisebbnek, munkahelyváltási szándékuk pedig jelentôsen nagyobbnak bizonyult. Az alulmotiváltak élettel és munkával való elégedettségének átlagpontszámai szignifikánsan a legalacsonyabbak, emellett munkahelyváltási szándékuk nekik a legnagyobb. A külsôleg motivált és kiegyensúlyozott klaszterekkel megegyezó mértékben, az alulmotiváltak jelentôsen több stresszt észlelnek munkahelyükön, mint a belsôleg és a rendkívül motivált klaszterek. 


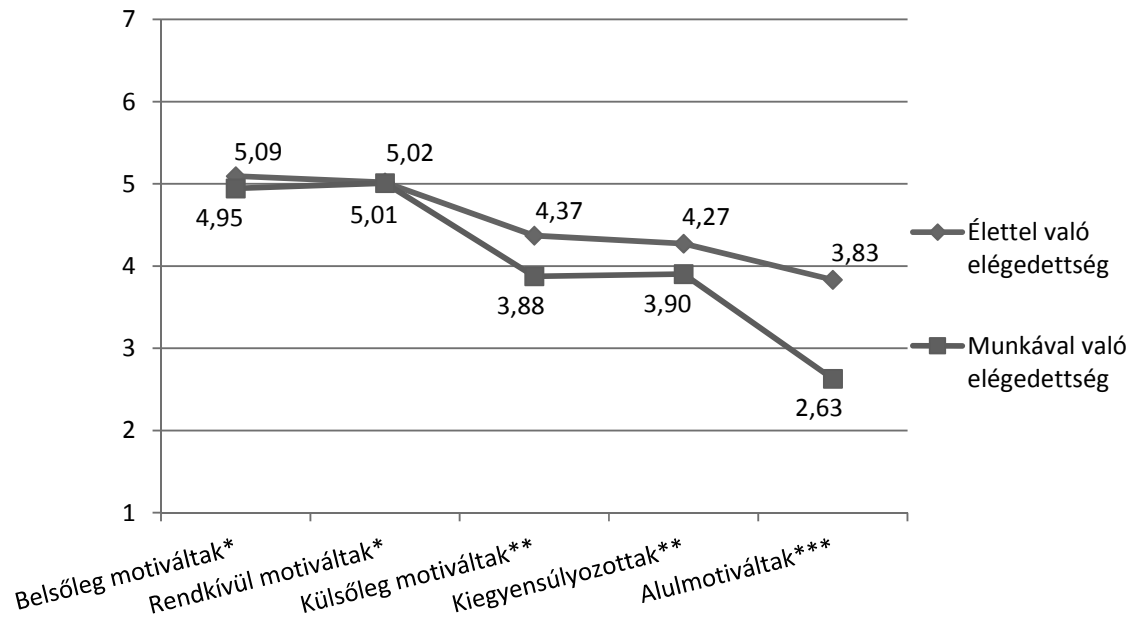

4. ábra. Az egyes profilok élettel és munkával való elégedettségének átlagpontszámai. Mindkét skála tartománya 1-7-ig terjed, ahol az 1-es érték azt jelöli, hogy a válaszadó egyáltalán nem ért egyet az adott állítással, a 7-es érték pedig azt, hogy tökéletesen egyetért. Az eltérô számú *-gal jelölt profilok átlagpontszámai szignifikánsan eltérnek

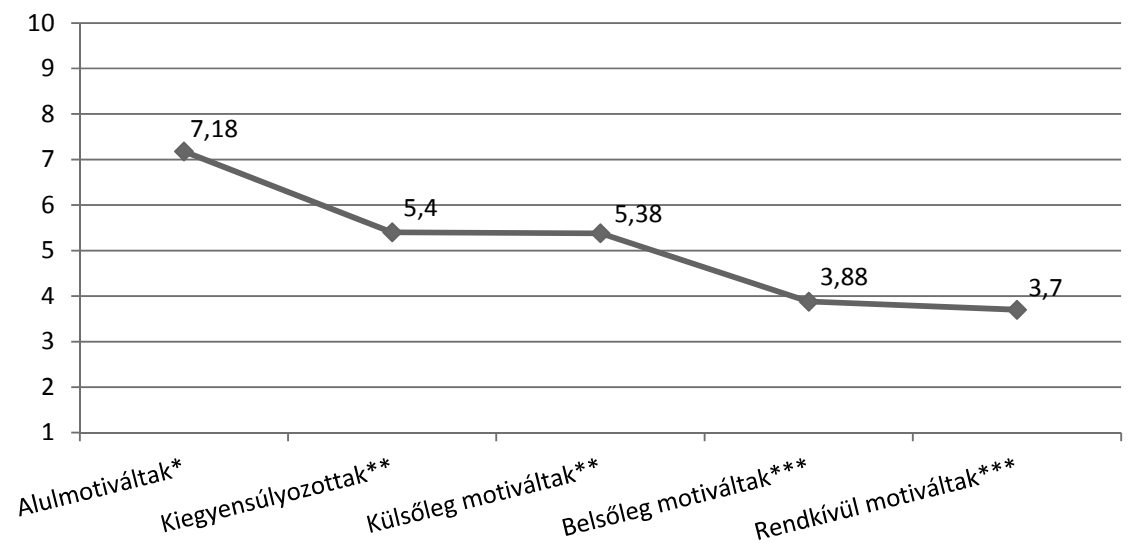

5. ábra. Az egyes profilok munkahelyváltási szándékának átlagpontszámai. A skála tartománya 1-10-ig terjed, ahol az 1-es érték azt jelöli, hogy a válaszadó soha, a 10-es érték pedig azt, hogy nagyon gyakran gondol arra, hogy új munkahelyet keres magának. Az eltérô számú *-gal jelölt profilok átlagpontszámai szignifikánsan eltérnek 


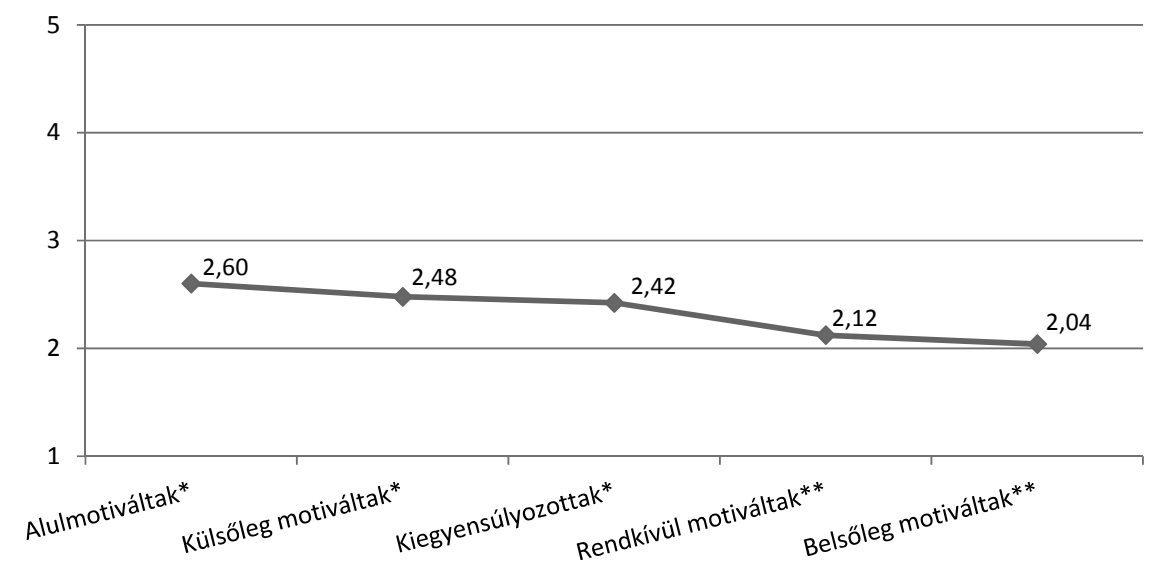

6. ábra. Az egyes profilok munkahelyen észlelt stressz-átlagpontszámai. A skála tartománya 1-5-ig terjed, ahol az 1-es érték azt jelöli, hogy a válaszadó soha, az 5-ös érték pedig azt, hogy nagyon gyakran élte át az adott állításban szereplő élményeket a munkahelyén. Az eltérő számú *-gal jelölt profilok átlagpontszámai szignifikánsan eltérnek

\section{MEGVITATÁS}

\section{A profilok}

Jelen kutatás Moran, Diefendorff, Kim és Liu (2012) tanulmányához hasonlóan öt munkahelyi motivációs klasztert talált a vizsgált mintában. A profilok az öndetermináció elméletét (Deci és Ryan, 2000) alapul véve négy, egymástól minôségileg eltérô motivációtípus - az extrinzik motiváció, introjektált szabályozás, identifikált szabályozás és intrinzik motiváció - mentén különültek el egymástól, és statisztikailag jelentôs különbséget mutattak e típusok mennyiségi vonatkozásában. A kutatásban elkülönült öt klaszter (1) egy „belsôleg motivált”, (2) egy „kiegyensúlyozott”, (3) egy „rendkívül motivált”, (4) egy „alulmotivált” és (5) egy „külsôleg motivált” profilt takar.

A „belsôleg motivált” profil 442 fớt (a minta 26,6\%-a) foglal magába. Alacsony mértékú extrinzik motivációval, közepes mértékú introjektált szabályozással, továbbá magas identifikált szabályozással és intrinzik motivációval jellemezhetô. A „kiegyensúlyozott” klaszter egy 289 fős (a minta 17,4\%-a) profil, melyet minden motivációtípus (extrinzik motiváció, introjektált szabályozás, identifikált szabályozás, intrinzik motiváció) tekintetében közepes mértékú motiváltság jellemez. A „rendkívül motivált” profil 454 fớt (a minta 27,3\%-a) számlál, és mindegyik motivációtípus tekintetében magas motiváltság jellemzi, kiváltképp az identifikált szabályozást és az intrinzik motivációt illetôen. Az „alulmotivált” profil a legkisebb létszámú, 126 fôs (a minta 7,6\%-a) klaszter, mely jelentôsen alacsony introjektált és identifikált szabályozással, szintén alacsony intrinzik motivációval, továbbá ezeknél némileg magasabb, közepes mértékú extrinzik motivációval jellemezhetô. A „külsôleg motivált” profil létszáma 351 fô (a minta 21,1\%-a), és magas extrinzik motiváció, közepesen magas introjektált, közepes mértékú identifikált szabályozás, valamint közepesen alacsony intrinzik motiváció jellemzi. 


\section{Hipotéziseink}

A jelen kutatásban feltárt profilok elsố feltételezésünkkel ellentétben csak részben mutatnak azonosságot a korábbi kutatásokban gyakran megjelenô munkahelyi motivációs mintázatokkal (Gillet és mtsai, 2017; Graves és mtsai, 2015; Howard és mtsai, 2016; Jansen in de Wal és mtsai, 2014; Moran és mtsai, 2012; Van den Berghe és mtsai, 2014). Elsố hipotézisünkben ugyanis azt feltételeztük, hogy kutatásunk során elkülönül majd egy „önirányított” profil közepes mértékű extrinzik motivációval, magas introjektált, identifikált szabályozással és magas intrinzik motivációval, egy „közepesen motivált" profil közepes mértékú extrinzik és intrinzik motivációval, és szintén közepes mértékú introjektált és identifikált szabályozással, valamint egy „autonóm” profil, melyet alacsony extrinzik motiváció, közepes mértékú introjektált szabályozás, valamint magas identifikált szabályozás és intrinzik motiváció jellemez. Hipotézisünk részben igazolódott, ugyanis a három feltételezett profil közül két - a hipotézisben „közepesen motivált” és „autonóm” profilként szereplô - klaszter megjelent kutatásunkban. Mi a „kiegyensúlyozott” és „belsőleg motivált” nevet adtuk ezeknek a klasztereknek. A magas introjektált és autonóm szabályozással jellemezhetố csoport azonban a mi mintánkban nem jelentkezett önállóan, illetve a „rendkívül motivált” klaszter esetében ehhez magas extrinzik motiváció is társult. Úgy túnik, hogy a külsố jutalmak fontossága az általunk vizsgált mintában szorosan összefügg a belsôvé tett kényszerek, szorongások meglétével.

A klaszterstruktúrák különbségei kulturális különbségeket jelezhetnek. Érdemes megemlíteni, hogy a korábbi, munkahelyi motivációs profilokat vizsgáló hét kutatásból három felmérés nem vagy csak kisebb részben zajlott Európában (Graves és mtsai, 2015; Howard és mtsai, 2016; Moran és mtsai, 2012), az európai felmérések pedig Hollandiára, Belgiumra és Franciaországra korlátozódtak (Howard és mtsai, 2016; Jansen in de Wal és mtsai, 2014; Van den Berghe és mtsai, 2014; Van den Broeck és mtsai, 2013). Ahogyan arra Ratelle és munkatársai (2007) rámutattak, a profilok kialakulása érzékeny lehet a tágabb kontextusra. Így jelen kutatásunk eredményei magukon hordozhatják a magyarországi vezetési és munkahelyi kultúra hatásait, például a munkahelyi autonómia eltérô szerepét is (vö. Roe, Zinovieva, Dienes és Ten Horn, 2000). Egy összehasonlító kutatásban (vö. Roe, Zinovieva, Dienes és Ten Horn, 2000) például azt találták, hogy az autonómia tapasztalata magyar munkavállalók esetében jóval gyengébben jelezte elôre a munkával kapcsolatos elkötelezettséget és bevonódást, mint a holland munkavállalóknál (megjegyzendố viszont, hogy a bolgár válaszadók esetében az autonómiának nem is volt szerepe a végleges modellben). Bakacsi és Sarkadi-Nagy (2003) kutatásaiból kiderül például, hogy a magyar vezetôkkel kapcsolatban megfogalmazott elvárások között alacsonyabb a jelentôsége az autonómiának és nagyobb a „karizmatikusságnak” (azaz a vezetôi inspiráció és befolyásolás elvárásának), mint például a német vagy a közép-európai vezetési környezetben. Valószínú, hogy ez öszszefüggésben van a munkavállalókkal kapcsolatban képviselt vezetôi magatartással is, így a munkavállalói kezdeményezés és autonómia kiemelt támogatása helyett a hazai vezetési kultúra könnyebben mozdul a vezetôii befolyásolás egyéb, esetenként kontrolláló módjai irányába. Ennek a két kutatási területnek (szervezeti és vezetési kultúra és munkavállalói motiváció) az összekapcsolása azonban további vizsgálatokat igényel. 
Második hipotézisünk, mely szerint az autonóm módon motivált profil(ok) esetén statisztikailag jelentôs mértékben magasabb lesz a három alapszükséglet kielégítettsége, igazolódott, ugyanis a leginkább autonóm szabályozású „rendkívül motivált” és „belsôleg motivált” klaszter a többi profilnál szignifikánsan több autonómia-, kompetencia- és kapcsolatélményt tapasztal a munkahelyén. A „külsôleg motiváltak” és a „kiegyensúlyozottak” közepes mértékben autonóm szabályozású klaszterek, ennek megfelelóen a munkahelyen megélt pszichológiai alapszükségleteik is közepes mértékben kielégítettek, míg a legkevésbé autonóm „alulmotivált” profil éli meg legkevésbé munkahelyén az autonómia, kompetencia és kapcsolódás élményét. Mindezt alátámasztja, hogy az autonóm szabályozás szignifikánsan pozitív együttjárást mutat a három pszichológiai alapszükséglet kielégítettségével, vagyis minél magasabban autonóm szabályozású valaki, annál több autonómia-, kompetencia- és kapcsolódásélményt tapasztal munkahelyén. Ezek a megállapítások egybecsengenek a korábbi kutatások eredményeivel (Jansen in de Wal és mtsai, 2014; Moran és mtsai, 2012; Van den Berghe és mtsai, 2014), továbbá hozzájárulnak az öndeterminációs elmélet azon megállapításának igazolásához, mely szerint az autonómia, kompetencia és kapcsolódás iránti szükségleteink alapszükségletek, melyek megfelelô kielégülése elegendhetetlen az autonóm szabályozás megvalósulásához, és ezáltal annak minden pozitív következményéhez is (Deci és Ryan, 2000).

A klasztereket megvizsgáltuk továbbá az élettel és a munkával való elégedettség (mint lehetséges pozitív tapasztalatok) tekintetében, illetve a munkahelyváltási szándék és a munkában észlelt stressz (mint lehetséges negatív tapasztalatok) vonatkozásában. A két leginkább autonóm szabályozású profil, a „rendkívül” és a „belsôleg motiváltak" szignifikánsan elégedettebbek életükkel és munkájukkal is, mint a másik három klaszter. A „külsôleg motiváltak” és a „kiegyensúlyozottak” nem különböznek a két pozitív következmény tekintetében, az „alulmotiváltak” azonban statisztikailag jelentôs mértékben elégedetlenebbek mindkét vonatkozásban, mint az összes többi profil. A negatív következményeket illetôen az „alulmotiváltak” észlelik szigifikánsan a legtöbb stresszt munkájukban, és ốk azok, akikben szignifikánsan magasabb a munkahelyváltási szándék, mint a többi profil esetén. A „rendkívül” és a „belsôleg motivált” profil nem különbözik e tekintetben sem: a két klaszter egyaránt jelentôsen kevésbé van kitéve a negatív következményeknek, mint az összes többi profil. Ezek a megállapítások egybecsengenek Graves és munkatársai (2015) eredményeivel, miszerint a belsôleg (is) motivált profilok a legelégedettebbek munkájukkal, és a kevésbé intrinzik módon motivált klaszterek munkahelyváltási szándéka jelentôsen magasabb, mint a magas autonóm motivációval rendelkezó profiloké.

\section{További következtetések}

Az autonóm és a kontrollált motivációt leggyakrabban egymással szembehelyezik, ezért különösen érdekesnek bizonyult, hogy kutatásunkban egy olyan profil is megjelent, mely mind belsôleg, mind külsôleg erôsen motivált („rendkívül motivált” profil). Ez a profil bizonyos szempontból motivációs tehetségként is értelmezhetô. A motivációs tehetség fogalma a különbözô motivációtípusok egyidejú jelenlétét feltételezi, 
egy-egy motívum domináns volta nélkül. Egy motivációs tehetség ugyanis több motivációs komponensbôl álló repertoárral rendelkezik, és képes arra, hogy ezt a fejlett motívumrendszert egy-egy helyzetben mindig optimális kombinációban mobilizálja. Ezzel a képességgel az egyén motivált tud maradni, hiszen az adott környezet kívánalmaihoz adaptívan tud alkalmazkodni (Fülöp, 2017).

Az öndetermináció elmélete szerint nem a motiváció mennyisége, hanem annak minôsége az, ami lényeges az optimális múködés szempontjából (Deci és Ryan, 2000). Felmerül tehát a kérdés, hogy a mennyiségileg és minôségileg is igen motivált klaszter pozitívabb kimeneteleket jelez-e előre, mint a „belsôleg motivált” klaszter, mely nagy mennyiségben „csupán” „jó” minôségú, belsô motivációval rendelkezik? Kutatásunkban azt találtuk, hogy a „rendkívül motivált” profil minden vizsgált változó - vagyis az autonóm szabályozás, a munkahelyen megélt autonómia-, kompetencia- és kapcsolódásélmény, továbbá a pozitív és negatív következmények - tekintetében megegyezik a „belsôleg motivált” profillal, vagyis azzal a klaszterrel, melynek szabályozása közepes mértékben kontrollált és magasan autonóm. Van den Broeck és munkatársai (2013) is hasonló eredményekre jutottak, ugyanis ók sem találtak jelentôs különbséget a magasan autonóm-alacsonyan kontrollált és magasan autonóm-magasan kontrollált profil pozitív és negatív következményekkel való összefüggései között.

A két profilnál azonos mértékben magasan kielégített három alapszükséglet alátámasztja Deci és Ryan (2000) azon meglátását, mely szerint ezek nélkül nincs autonóm szabályozás és optimális múködés. A két profil ezen felül azonos mértékben elégedett munkájával és életével is, vagyis úgy tûnik, hogy a „rendkívül motiváltak” esetén megjelenô nagymértékú kontrollált szabályozás nemcsak hogy megfér az autonóm szabályozással, hanem mit sem von le annak pozitív következményeiból. Hasonló eredményre jutottak e tekintetben Moran és munkatársai (2012), akik kutatásukban azt találták, hogy a munkahelyi teljesítmény akkor a legjobb, ha minden motivációtípus (vagyis mind a belsô, mind a külsô motivációk) szintje magas, de további kutatások is azt bizonyítják, hogy a magas kontrollált szabályozás megléte önmagában nem tûnik lényegesnek akkor, ha magas autonóm motiváció is társul hozzá (Graves és mtsai, 2015; Howard és mtsai, 2016; Strauss és mtsai, 2017; Van den Berghe és mtsai, 2014; Van den Broeck és mtsai, 2013).

Az egyes motivációtípusok következményeivel kapcsolatban számos korábbi, munkahelyi motivációs profilokat vizsgáló tanulmány is hasonló eredményekre jutott (Gillet és mtsai, 2017; Graves és mtsai, 2015; Howard és mtsai, 2016; Jansen in de Wal és mtsai, 2014; Moran és mtsai, 2012; Van den Berghe és mtsai, 2014), ezzel is alátámasztva, hogy bár a kutatásokban megjelenô profilok nem minden esetben fedik egymást, a külsô-belsô szabályozásra utaló konzisztensen megjelenô tendenciák igazolják az öndetermináció elméletének univerzális és kultúrától független voltát (Deci és Ryan, 2000). Továbbá a megállapítások egybecsengenek az öndetermináció elméletének azon megfontolásaival, miszerint a három alapszükséglet megfelelô kielégítése elengedhetetlen az autonóm szabályozás létrejöttéhez, valamint a folyamatban lévó pszichológiai fejlődéshez, integritáshoz és jólléthez, illetve, hogy az alapszükségletek kielégítésének korlátozása kontrollált szabályozáshoz vezet, mely negatív következményekkel hozható összefüggésbe (Deci és Ryan, 2000). 
Deci és Ryan (2000) elmélete szerint az ember aktív, növekedésorientált organizmus, mely természeténél fogva intrapszichés és interperszonális integrációra törekszik. A dolgozók motiválását illetôen tehát arra (is) érdemes figyelmet fordítani, hogy olyan munkakörülményeket teremtsünk, melyek teret engednek az ember azon természetes folyamatainak, melyek a három alapszükséglet kielégítését szolgálják. A kompetenciaélmény gyakoribb megélése például olyan feladatok/tevékenységek biztosításával érhetố el, melyek elegendô izgalmat, elkötelezôdést és élvezetet nyújtanak az egyén számára, mert egy optimális kihívás sikeres teljesítésével az egyén kompetensnek érezheti magát (Deci és Ryan, 2000). Az autonómia szükségletének kielégítéséhez hozzájárulhat például, ha az egyénnek szabad teret adunk bizonyos döntésekben és/vagy véleménye, ötletei szabad kinyilvánításában (ezek kompetenciaélményt is adhatnak), a munkahelyi kapcsolatélményt például közös terek kialakításával és a munkatársi kapcsolatok erôsítésével növelhetjük.

\section{A kutatás korlátai}

Kutatásunkban a magyar munkavállalók tekintetében nem reprezentatív mintával dolgoztunk, így eredményeink értelmezésének széles körú kiterjesztése csak korlátozottan lehetséges. Az összefüggések elemzése során továbbá keresztmetszeti adatokra támaszkodtunk, ami az okozás irányának megállapítására nem ad módot. A kutatás további korlátja, hogy viszonylag heterogén munkavállalói mintával dolgoztunk, melyben eltérô arányban szerepeltek például részmunkaidóben vagy képzés mellett munkát vállalók (pl. egyetemi hallgatók), illetve teljes állásban foglalkoztatottak. További, célzott mintavételen alapuló kutatások szükségesek annak feltérképezéséhez, hogy ezeknek a csoportoknak milyenek a sajátos motivációs jellemzőik.

\section{ÖSSZEFOGLALÁS, KITEKINTÉS}

Összességében elmondhatjuk, hogy eredményeink alátámasztják Deci és Ryan (2000) motivációs elméletének számos vonatkozását. Kutatásunk rámutat, hogy a nagymértékú belsố motiváció megléte magasabb jólléti mutatókat hoz magával, még abban az esetben is, ha ehhez nagymértékú külsô motiváció is társul. A dolgozók motiválását illetốen tehát arra (is) érdemes figyelmet fordítani, hogy olyan munkakörülményeket teremtsünk, melyek teret engednek az ember azon természetes folyamatainak, melyek a három alapszükséglet kielégítését szolgálják. Ezek kielégítése ugyanis lehetôvé teszi az autonóm szabályozás kialakulását és fennmaradását, melynek köszönhetôen az egyén nemcsak hogy jobbnak érzi egészségi állapotát és elégedettebb életével, hanem jobban teljesít munkahelyén (Moran és mtsai, 2012), kevésbé van kitéve a kiégés és a szorongás veszélyének (Gillet és mtsai, 2017; Howard és mtsai, 2016; Van den Berghe és mtsai, 2014; Van den Broeck és mtsai, 2013), továbbá munkájával is elégedettebb és elkötelezettebb (Gillet és mtsai, 2017; Graves és mtsai, 2015; Howard és mtsai, 2016; Van den Broeck és mtsai, 2013), és viselkedése hosszabb távon fennmarad (Deci és Ryan, 2000; Teixeira és mtsai, 2012). Ezen felül minél inkább önirányított az egyén, 
annál eredményesebben halad céljai felé (Koestner és mtsai, 2008) és annál pozitívabb a munkahelyhez való hozzáálása (Graves és mtsai, 2015). Tehát, ha a dolgozó azért végzi munkáját, mert az személyes meggyôzôdéseivel és értékeivel kongruens, élvezi és érdekesnek tartja azt (vagyis motivációja belsô), a személyes pozitív következmények mellett a munkahelyén is kedvezóbb kimenetelek várhatóak.

\section{IRODALOM}

Bakacsi, Gy., Sarkadi-Nagy, A. (2003). Latinos magyar Leadership - vezetésfelfogásunk a Globekutatás tükrében. Alkalmazott Pszichológia, 3-4, 7-26.

Bergman, L. R., \& Lundh, L.-G. (2015). The Person-Oriented Approach: Roots and Roads to the Future. Journal for Person-Oriented Research, 1(1-2), 1-6.

Bergman, L. R., Magnusson, D., \& Khouri, B. M. E. (2003). Studying Individual Development in An Interindividual Context: A Person-oriented Approach. Psychology Press.

Deci, E. L., \& Ryan, R. M. (2000). The "what" and "why" of goal pursuits: Human needs and the self-determination of behavior. Psychological Inquiry, 11(4), 227-268. https://doi. org/10.1207/S15327965PLI1104_01

Deci, E. L., \& Ryan, R. M. (2008). Self-determination theory: A macrotheory of human motivation, development, and health. Canadian Psychology/Psychologie Canadienne, 49(3), 182-185. https://doi.org/10.1037/a0012801

Deci, E. L., Ryan, R. M., Gagné, M., Leone, D. R., Usunov, J., \& Kornazheva, B. P. (2001). Need satisfaction, motivation, and well-being in the work organizations of a former eastern bloc country: A cross-cultural study of self-determination. Personality and Social Psychology Bulletin, 27(8), 930-942.

Friederichs, S. A., Bolman, C., Oenema, A., \& Lechner, L. (2015). Profiling physical activity motivation based on self-determination theory: A cluster analysis approach. BMC Psychology, 3, 1. https://doi.org/10.1186/s40359-015-0059-2

Fülöp M. (2017). A motiváló iskola. In Hunyady Gy., Csapó B., Pusztai G., Szivák J. (szerk.), Az oktatás korproblémái (pp. 104-129). Budapest: ELTE Eötvös Kiadó.

Gagné, M., Forest, J., Vansteenkiste, M., Crevier-Braud, L., Broeck, A. van den, Aspeli, A. K., ... Westbye, C. (2015). The Multidimensional Work Motivation Scale: Validation evidence in seven languages and nine countries. European Journal of Work and Organizational Psychology, 24(2), 178-196. https://doi.org/10.1080/1359432X.2013.877892

Gillet, N., Fouquereau, E., Vallerand, R. J., Abraham, J., \& Colombat, P. (2017). The Role of Workers' Motivational Profiles in Affective and Organizational Factors. Journal of Happiness Studies, 1-24. https://doi.org/10.1007/s10902-017-9867-9

Graves, L. M., Cullen, K. L., Lester, H. F., Ruderman, M. N., \& Gentry, W. A. (2015). Managerial motivational profiles: Composition, antecedents, and consequences. Journal of Vocational Behavior, 87, 32-42. https://doi.org/10.1016/j.jvb.2014.12.002

Howard, J., Gagné, M., Morin, A. J. S., \& Van den Broeck, A. (2016). Motivation profiles at work: A self-determination theory approach. Journal of Vocational Behavior, 95-96, 74-89. https:// doi.org/10.1016/j.jvb.2016.07.004

Jansen in de Wal, J., den Brok, P. J., Hooijer, J. G., Martens, R. L., \& van den Beemt, A. (2014). Teachers' engagement in professional learning: Exploring motivational profiles. Learning and Individual Differences, 36, 27-36. https://doi.org/10.1016/j.lindif.2014.08.001 
Kasser, T., \& Ryan, R. M. (1996). Further Examining the American Dream: Differential Correlates of Intrinsic and Extrinsic Goals. Personality and Social Psychology Bulletin, 22(3), 280-287. https://doi.org/10.1177/0146167296223006

Koestner, R., Otis, N., Powers, T. A., Pelletier, L., \& Gagnon, H. (2008). Autonomous motivation, controlled motivation, and goal progress. Journal of Personality, 76(5), 1201-1230. https://doi.org/10.1111/j.1467-6494.2008.00519.x

Központi Statisztikai Hivatal (2017. április). Magyarország, 2016. Dr. Vukovich Gabriella (felelốs kiadó; online). Nyilvántartási szám: Y/15319. Elérhetô: http://www.ksh.hu/docs/hun/ xftp/idoszaki/mo/mo2016.pdf. Letöltés dátuma: 2018.01.18.

Martos T. (2009). Célok, tervek, törekvések. II. A személyes célok és életcélok kapcsolata - módszertani kérdések és demonstráció. Magyar Pszichológiai Szemle, 64(3), 573-592.

Martos T. (2016). Motiváció, értékek és társas kapcsolatok: az öndetermináció elméletének alapjai. In Baritz S. L., \& Dabóczi G. (szerk.), Emberközpontú gazdaság: A Keresztény Társadalmi Elvek a Gazdaságban (KETEG) képzés szakkönyve (pp. 242-255). Budapest, Magyarország: KETEG Oikonomia Kutató Intézet Alapítvány.

Martos T., Sallay V., Désfalvi J., Szabó T., \& Ittzés, A. (2014). Az Élettel való Elégedettség Skála magyar változatának (SWLS-H) pszichometriai jellemzõi. Mentálhigiéné és Pszichoszomatika, 15(3), 289-303. https://doi.org/10.1556/Mental.15.2014.3.9

Matuszka B., Csuka S., Hódos E., Nagy A., Pálffy P., Sallay V., \& Martos T. (2018). A Többdimenziós Munkamotiváció Kérdôív magyarországi adaptációja. Kézirat közlésre benyújtva

Moran, C. M., Diefendorff, J. M., Kim, T.-Y., \& Liu, Z.-Q. (2012). A profile approach to self-determination theory motivations at work. Journal of Vocational Behavior, 81(3), 354-363. https:// doi.org/10.1016/j.jvb.2012.09.002

Ratelle, C. F., Guay, F., Vallerand, R. J., Larose, S., \& Senecal, C. (2007). Autonomous, Controlled, and Amotivated Types of Academic Motivation: A Person-Oriented Analysis. Journal of Educational Psychology, 99(4), 734-746.

Roe, R., Zinovieva, I., Dienes, E., \& Ten Horn, L. (2000). A Comparison of Work Motivation in Bulgaria, Hungary, and the Netherlands: Test of a Model. Applied Psychology, 49(4), 658-687. https://doi.org/10.1111/1464-0597.00039

Stauder A., \& Konkoly Thege B. (2006). Az észlelt stressz kérdőív (PSS) magyar verziójának jellemzői. Mentálhigiéné és Pszichoszomatika, 7(3), 203-216.

Strauss, K., Parker, S. K., \& O'Shea, D. (2017). When does proactivity have a cost? Motivation at work moderates the effects of proactive work behavior on employee job strain. Journal of Vocational Behavior, 100, 15-26. https://doi.org/10.1016/j.jvb.2017.02.001

Takács Sz., Makrai B., \& Vargha A. (2015). Klasszifikációs módszerek mutatói. Psychologia Hungarica, 3(1), 67-88.

Teixeira, P. J., Carraça, E. V., Markland, D., Silva, M. N., \& Ryan, R. M. (2012). Exercise, physical activity, and self-determination theory: A systematic review. https://doi. org/10.1186/1479-5868-9-78

Van den Berghe, L., Soenens, B., Aelterman, N., Cardon, G., Tallir, I. B., \& Haerens, L. (2014). Within-person profiles of teachers' motivation to teach: Associations with need satisfaction at work, need-supportive teaching, and burnout. Psychology of Sport and Exercise, 15(4), 407-417. https://doi.org/10.1016/j.psychsport.2014.04.001

Van den Broeck, A., Lens, W., De Witte, H., \& Van Coillie, H. (2013). Unraveling the importance of the quantity and the quality of workers' motivation for well-being: A person-centered perspective. Journal of Vocational Behavior, 82(1), 69-78. https://doi.org/10.1016/j. jvb.2012.11.005 
Vansteenkiste, M., Sierens, E., Soenens, B., Luyckx, K., \& Lens, W. (2009). Motivational profiles from a self-determination perspective: The quality of motivation matters. Journal of Educational Psychology, 101(3), 671.

Vargha, A., Bergman, L. R., \& Takács, Sz. (2016). Per-forming cluster analysis within a person-oriented context: Some methods for evaluating the quality of clustersolutions. Journal of Person-oriented Research, 2(1-2), 78-86.

Vargha, A. (2016). A ROPstat statisztikai programcsomag. Statisztikai Szemle, 94(11-12), $1165-1192$.

Vargha, A., Torma, B., \& Bergman, L. R. (2015). ROPstat: a general statistical package useful for conducting person-oriented analyses. Journal of Person-Oriented Research, 1(1-2), 87-97.

\title{
WORK MOTIVATION AND SATISFACTION - A PERSON-CENTERED APPROACH
}

\author{
FÉNYSZÁROSI, ÉVA - SALLAY, VIOLA - MATUSZKA, BALÁZS - MARTOS, TAMÁS
}

Job takes an important part in most adults' life, therefore, work motivation plays a significant role in peoples' everyday functioning. Using Self-determination Theory as a guiding framework we identified work motivation patterns in a sample of 1662 Hungarian employees. Cluster analysis of the subscale scores of the Multidimensional Work Motivation Scale (Gagné et al., 2015) revealed five work motivation clusters, which we labeled (1) "intrinsically motivated", (2) "balanced", (3) "extremely motivated", (4) "poorly motivated" and (5) "extrinsically motivated". Further analysis has shown that the employee groups, represented by these clusters, differed significantly in their experiences of the three basic psychological needs: autonomy, competence and relatedness. In addition, satisfaction with life and with job as well as perceived workplace stress and turnover intentions were consistently different across the clusters. We may conclude that patterns of work motivation may have a differential impact on people's well-being and thereby on their everyday life too. Further conclusions concerning motivational and organizational psychology are also discussed.

Keywords: work motivation, self-determination theory, satisfaction with work, person-centred approach, cluster analysis 